\title{
Construction of Quality Assurance System for Engineering Specialty Based on Professional Certification
}

\author{
Zhang Xingfu \\ Academic Affairs Office \\ Jiamusi University \\ Jiamusi, Heilongjiang 154007 \\ 292587870@qq.com \\ Ma Xiaojun* \\ School of Mechanical Engineering \\ Jiamusi University \\ Jiamusi, Heilongjiang 154007 \\ mjzx2009phd@163.com
}

\author{
Yang Abin \\ Employment Office \\ Jiamusi University \\ Jiamusi, Heilongjiang 154007
}

\author{
Li Chunjiang \\ Academic Affairs Office \\ Jiamusi University \\ Jiamusi, Heilongjiang 154007
}

\begin{abstract}
At present, China is a high engineering education country. In order to achieve the connotative development of higher engineering education, improve the quality of education, professional certification is carried out in institutions of higher learning, which will comprehensively promote the reform of higher engineering education and the quality of personnel training. The construction of professional quality assurance system which is based on the professional certification derived from the hot issues of higher engineering education reform. It analyzed the present professional certification and quality assurance system status in China and strengthened the top-level design of quality engineering construction of engineering education. Multi-measures have been taken simultaneously to comprehensively promote the construction of higher engineering education quality assurance system.
\end{abstract}

Keywords-Engineering education; professional certification; quality assurance; deep integration

\section{INTRODUCTION}

Deepening the reform of higher engineering education, improving the quality of personnel training, and taking the connotative development road is the prerequisite to realize the scientific and sustainable development of higher engineering education. With the merger of higher education institutions, the enlargement of enrollment scale and the scale expansion of higher engineering colleges and universities, the limited resources and excellent engineering education teachers lead to the decline of the quality of engineering personnel training in colleges and universities. The quality of personnel training in the engineering course of higher engineering education is improved through professional certification, strengthening the teaching resources, improving teaching conditions, perfecting the curriculum system and quality standards. In 2016, China became an official member of the "Washington Agreement", which indicated the international recognition of Chinese

Fund project: the education and teaching research program of Jiamusi University: (2016JW10092017LGL-007)

*Correspondence Author:Ma Xiaojun(1976-),master tutor professional certification. Through the deep development of professional certification, institutions of higher learning can further clarify the professional positioning of engineering, training objectives and professional construction direction, condense school-running characteristics, improve the engineering quality standards and quality assurance and supervision system, concentrate on students and start from quality construction, forming a quality closed loop of higher engineering education.

\section{The Present Situation of Professional Certification AND QUALITY ASSURANCE SYSTEM}

\section{A. The Present Situation of Engineering Education Specialty Certification}

China's professional certification of engineering education started from 1992, the Ministry of Construction carried out professional certification work in six specialties including civil engineering architecture, civil engineering, city planning and so on. In 2007, the Ministry of Education set up a professional committee of engineering education certification and established enginery and chemical engineering these two professional certification subcommittee and electrical appliances, computer, geological and mining specialties, light industry and food, communications and transportation, environment and water conservancy and hydraulic engineering these 7 professional certification pilot groups. In the same year, the General Office of the Ministry of Education issued "A Notice on the Establishment of the Supervision and Arbitration Commission of National Engineering Education Professional Certification", which established China's organization system of engineering education certification. In 2013, China proposed to take part in the "Washington Agreement". In 2016, we became a member of the "Washington Agreement". According to the "Washington Agreement", the realization of 
standardization and internationalization of engineering education and the promotion of the quality standard of personnel training in engineering education in China share the same requirement with the "Washington Agreement". Promoting the deep integration of engineering education and engineering enterprises is of great significance in improving the level of higher engineering education and the professional ability of modern engineers and achieving the strategic goals of national innovation-driven development and Chinese intelligent manufacturing.

\section{B. The Current Situation of Engineer Education Quality}

Since the reform and opening up, China has implemented the national innovation-driven strategy, intelligent manufacturing, green manufacturing, supply side structural reform. So, higher engineering education in China develops quickly and is becoming more and more perfect in the number, size, and structure and cultivation system. The engineering education specialty oriented, student-centered and the improvement of the quality of higher engineering education are opportunities and challenges faced by the engineering colleges and universities. In order to strengthen the quality of education in higher engineering, Evaluation Center of the Ministry of Education issued "Chinese Engineering Education Quality Report" annually since 2012. It monitored the teaching quality by using "big data" on the national higher education data platform. Now, we have constructed the quality standard and guarantee system which are in line with the world higher engineering education and conform to characteristics of Chinese higher engineering education by combining with the present situation of the quality of Higher Engineering Education in China and learning from the advanced concept of evaluation on the quality of Higher Engineering Education in Europe and the United States and other countries. The quality standard and guarantee system are result oriented and pay attention to students' innovation ability and application ability. They are led by the engineering education accreditation and improve the quality of construction engineering continuously, implement outstanding talents and modern engineers training plan. All these effectively improve the quality of engineering education. But comparing with the developed countries in the world, there is still a gap. First is that part of the colleges and universities training orientation, our country's engineering talent training goal and social demand reached a low degree. Second is the lack of engineering education resources. The deep integration of universities, engineering and school enterprise is in the initial stage. Emphasis on theory and low practical ability result in the low innovation and practical ability of engineering education talents. Third is that the higher engineering education quality construction is lack of accurate implementation. Some colleges and universities engineering training mode is one-folded and characteristics are not obvious. Fourth is the lack of high-level engineering education teachers. Because the higher engineering education teachers are lack of enterprise experience, which results in teachers' low engineering ability and separates the content of teaching from reality.

\section{MEASURES In THE CONSTRUCTION OF QUALity ASSURANCE SYSTEM}

Engineering education professional certification is the carrier of engineering education in institutions of higher learning. The following goals can be achieved by applying professional certification: firstly, cultivation plan which is consistent with regional industrialization and new national industrialization can be established by clarifying professional orientation and training objectives. Secondly, professional certification is carried out deeply, which promotes the integration of production, teaching and research, strengthens the emergence of school and enterprise, school and school, school and region, improves students' innovation ability and practical ability, facilitates employment, so as to meet the demand of engineering enterprises for talents. Thirdly, the professional certification can further improve the quality of higher engineering education. The essence of professional certification is to connect with the international engineering education and achieve the essence of equivalent. Its connotation is to establish a perfect higher engineering education quality system and achieve normalization and quality. It focuses on the process of training and ensures the engineering education personnel training quality.

\section{A. Strengthening the Top-level Design of the Quality Engineering Construction of Engineering Education}

Since 2011, Ministry of Education and Ministry of Finance carried out the Undergraduate Teaching Quality and Teaching Reform Project., aiming at strengthening the higher education quality, strengthening the process of management, quality supervision and feedback and fostering students' innovation abilities and practical abilities. Engineering in Institution of Higher Education is tasked with innovation-driven development strategy, economic and social development, and the reserving of talents for MadeinChina2025 and the development strategy of new industrialization. In recent years, European and American countries have implemented the High Technology Development Strategy. Germany carried out Industry 4.0; The United Kingdom carried out The United Kingdom Industry 2050; The United States put forward the Advanced Manufacturing Strategic Planning. In the two sessions of 2015, the Premier of the State Council, Keqiang Li referred to "MadeinChina2025", which is focusing on a key line of a deep integration of informationization and industrialization, two manufacturings, that is intelligent manufacturing and green manufacturing and ten fields. "MadeinChina2025" represents the topmost and path selection of the transformation from a big country with manufacturing industry to a powerful manufacturing country in mechanical industry. The top-level design should be strengthened and the comprehensive reform of higher engineering education should be carried out scientifically and reasonably. It is of importance to combine the development trends of higher education at home and abroad, adhere to the core of quality engineering construction, take problem as orientation, have overall planning and all-round consideration, strengthen the system construction and improve the plan of engineering education. The main line of "serving the society and strengthening the quality of engineering education" should be adhered to. 


\section{B. Taking Various Measures and Promoting Higher} Engineering Education Reform Comprehensively

It is of great importance of taking various measures and promoting higher engineering education reform comprehensively. Firstly, various patterns of cooperation between schools and enterprises, colleges and institutes, schools and schools and colleges and local education governments should be adopted to optimize advantage resources. The joint training demonstration workstation for engineering students should be established and the innovation and practical platform for engineering students be set up and the production-teaching-study cooperation be advanced as well to explore the new higher engineering talents cultivating mode which is based on professional certification, explore researchoriented teaching, perfect practical teaching system and innovative teaching management model. With highly efficient promotion of professional accreditation, the excellent engineers training goal of "high level, deep connotation, and strong characteristics" can be realized to improve the quality of talent cultivation. Depending on the provincial key major, provincial experimental teaching demonstration center and other engineering education resources, training mode oriented towards the mechanical engineering talents with professional accreditation of engineering education is built, that is, in conjunction with requirement of the common criteria and supplementary criteria of machinery majors from National Engineering Education Professional Certification Standard (trial)", Ministry of Education, aiming at the cultivating highquality, innovative and applied talents, taking the of the schoolenterprise coalition as the platform, in the context of a practical engineering, taking the engineering application ability as a main line, we should actively carry out theoretical teaching and practical teaching reform, cultivate modern engineers who can meet the needs of economic development and industrial revitalizing and who are of engineering industry unique with coordinated development of the abilities and qualities.

We should learn from and absorb the advanced concepts, cultivating modes and systems and mechanisms of foreign engineering education, further develop the training mode cooperated by schools and enterprises and strengthen the construction of engineering teacher staffs in order to lay up talented persons for the achievement of innovation-driven development and new industrialization strategy. The key point of modern engineering education is to learn from the typical cases of professional certification and successful experience of foreign engineering education combining with the present situation of China engineering education to explore modern engineer cultivating modes that conform to China. First is to perfect engineering education certification system. International certification standards should be adopted and appraisal agencies should be marketized to regulate engineering education certification system that accords with Chinese engineering situation. Second is to set up diversified training models for modern engineers and integrate Multiplication resources such as governments, enterprises, teachers and students into modern engineering training system. With students as the center and open experimental projects, teacher research projects and college student innovation and entrepreneurship training program as platforms, project teaching method should be integrated into extra classes to cultivate students' innovation consciousness, innovation ability and practice ability. According to talent cultivation goal, students should be taken as the main body when project teaching method is implemented. We should lay emphasis on the course cultivation and encourage students to participate in various competitions relying on projects so that students' practice ability can be developed and cultivation quality can be improved, thus, guaranteeing students' full employment with quality, knowledge and skill support.

\section{IMPROVING QUALITY SECURITY SYSTEM OF ENGINEERING EDUCATION}

\section{A. Enhancing Investment and Improve Safeguards}

Firstly, the funds investment guarantee mechanism should be perfected. We should continue to expand the ways for obtaining engineering education funds, establish and improve the financial allocation system, improve the grants system for engineering college students, offer an easy way for students' enrollment, enhance investment in scholarships and academic scholarship, recruit outstanding students to the engineering majors of colleges and universities for further study. Secondly, appraisal inspection mechanism should be perfected. We should participate in international education quality assessment and certification by professional accreditation, carry out special appraisal, casual inspection and other methods for the engineering courses and implement achievements allocation so that financial allocation and the education quality are linked and the multi-level quality safeguard system with multiagent can be established gradually. Thirdly, information disclosure mechanism should be perfected. The basic database, the information web sites, the quality information platform of engineering education should be established in order to release basic information of engineering education in time and accept public supervision actively. Fourthly, the incentive system should be perfected. A special fund for engineering education should be established to encourage, support and guide the engineering colleges to be bold to explore and innovative in the students recruitment and selection, students training mode, tutorial system, evaluation and supervision mechanism and other aspects.

\section{B. Strategy to perfect quality guarantee system of talents training}

Material Science and Engineering discipline is the material engineering major of Jiamusi University with a long history, outstanding advantage and a good social prestige. After professional certification and assessment process, Material Science and Engineering discipline further defines its specialty orientation, professional goals and development direction. According to the "high quality, strong ability of applied talents" training objectives, it has further improved the quality guarantee system of professional talents training. The university has established Specialized Construction Direction Committee with participation of external professors and engineering experts to discuss major issues of professional construction, the finalization of a professional construction planning, personnel training programs, curricula and so on. Considering classroom teaching, teaching materials selection 
and verification, students network assessment of teaching materials, teaching files check at the beginning of term, network assessment of classroom teaching quality, leading experts in attendance, teaching supervisors in attendance and other methods have been implemented. To the test and examinations, the examination paper proposition quality verification, examination paper generalized analysis, and examination paper quality spot-check system are implemented. With regard to the practical teaching, the teaching laboratory special appraisal and the graduation fieldwork special appraisal system have been implemented. To the graduation design (thesis), the topic selection review, instructor selection, oral defense of designing scheme, medium-term inspection and inspection of defense qualification are monitored. The university and college have regular medium-term teaching examinations, teaching model classes, teaching diagnostic classes and teaching competitions for young teachers. Other activities such as seminars on communication between teachers and students, teaching seminars are hold to improves the teaching constantly. Meanwhile, the system of graduate followup and employer evaluation are established and improved to embody social demands in teaching in a timely manner.

\section{REFERENCES}

[1] [1] Sun Na. Analyses and Outlooks of the Development Current Status of Higher Engineering Education Certification in Our Country [J]. Innovation and Enterprise Education, 2016, (01): 29-34

[2] [2] Zhi Xizhe, Luo Xiangyang, Zhang Qingjiang. The Research of Construction of Science Specialties in Our Country in the View of PostWashington Accord [J]. Modern Education Science, 2015, (05): 69-74.

[3] [3] Chen Ping. The Connotative Development of Construction of Science Specialties Propelled by the Concept of Certification [J]. China University Teaching, 2014, (01):42-47.

[4] [4] Zhang Yan. The Research of Collegiate Certification Issues in Our Country [D]. Shenyang Normal University, 2012.

[5] [5] Wensong Chen. Engineering Education Professional Certification and Its Impact on Higher Engineering Education [J]. Higher Education Forum, 2011, (07):29-32.

[6] [6] Chen Yilin, He Xiaoqi, Ma Xiushui. The Exploration and Practice of Engineering Education Major Certification System in Applicationoriented University [J]. Modern Education Science, 2011, (03):78-82.

[7] [7] Sun Xiaolei, Yang Yingli, Niu Jincheng. Certification and Security Engineering Undergraduate Education [J]. Journal of Safety Science and Technology, 2011, (03):78-82.

[8] [8] Aihua Huang. Analysis of Teaching Quality Assurance System of Universities or Colleges in America and England [J]. Modern Education Science, 2011, (01):43-45.

[9] [9] Zhang Wenxue, Liu Junxia, Peng Jing. The Construction of Engineering Education Professional Certification System and Its Potential Impact on Higher Engineering Education [J]. Tsinghua Journal of Education, 2007, (06): 60-64+79.

[10] Fan Aihua. Research on Implementation Strategy on College Professional Certification in Our Country [D]. Wuhan University of Technology, 2007. 